\title{
Effect of Reaction Conditions on the Aqueous Oxidation of Sodium Phosphite by Mixed Gas of Oxygen and Sulfur Dioxide
}

- Aqueous oxidation of sodium phosphite by mixed gas of oxygen and sulfur dioxide (2nd Report) by Satoshi YAMASHITA ${ }^{\mathrm{a}}$, Takafumi KONDO ${ }^{\mathrm{b}}$ and Noboru MASUKO ${ }^{\mathrm{a}}$

a. Department of Metallurgical Engineering, Chiba Institute of Technology, 2-17-1 Tsudanuma, Narashino-shi 275-8588, Japan

b. Graduate Student, Chiba Institute of Technology (Present at Shin-Kobe Electric Machinery Co., Ltd., 2200

Oka, Okabe-cho, Osato-gun, Saitama 369-0297, Japan)

In the previous report, it was explained that $\mathrm{O}_{2}-\mathrm{SO}_{2}$ mixed gas oxidized the phosphorous acid to phosphoric acid. In this report, effects of reaction conditions, such as agitation speed, partial pressure of oxygen, $\mathrm{pH}$, and temperature, on the aqueous oxidation of $\mathrm{H}_{3} \mathrm{PO}_{3}$ by $\mathrm{O}_{2}-\mathrm{SO}_{2}$ mixed gas are investigated. The results were summarized as follows.

Agitation speed hardly changes over $1,000 \mathrm{~min}^{-1}$ on the oxidation rate of $\mathrm{H}_{3} \mathrm{PO}_{3}$. The oxidation rate of $\mathrm{H}_{3} \mathrm{PO}_{3}$ is proportional to the partial pressure of oxygen. The oxidation rate of $\mathrm{H}_{3} \mathrm{PO}_{3}$ increases with the increase of $\mathrm{pH}$. With the rise in solution temperature, the oxidation rate of $\mathrm{H}_{3} \mathrm{PO}_{3}$ increases, however, the temperature dependency is low. In all conditions of reaction, the quantity of $\mathrm{H}_{3} \mathrm{PO}_{3}$ oxidized did not exceed the quantity of $\mathrm{SO}_{2}$ oxidized. Within the range of these experimental conditions, the oxidation rate of $\mathrm{SO}_{2}$ was not affected.

KEY WORDS : Phosphonic Acid, Aqueous Oxidation, Oxidizing Agent, Sulfur Dioxide, Oxygen, Reaction Condition

\section{1. 緒言}

前報 1) において, $\mathrm{O}_{2}-\mathrm{SO}_{2}$ 混合気体が亜リン酸をリン酸まで酸 化することを述べ, 反応温度 $80^{\circ} \mathrm{C}$, 一定の攪拌条件の下で $\mathrm{H}_{3} \mathrm{PO}_{3}$ の初期濃度と酸素ガス中の $\mathrm{SO}_{2}$ 濃度を変化させたときの酸化反応 の変化を報告した。ここではこの反応が攪拌速度，気相中の酸素 分圧，pH，温度にどのように依存するかについて報告する。さら に反応に伴う $\mathrm{pH}$ 変化を一定に保つために加えた $\mathrm{NaOH}$ 量を測定 し, 前報の結果と併せて総合的に $\mathrm{O}_{2}-\mathrm{SO}_{2}$ 混合ガスによる亜リン 酸の液相酸化の反応機構に関する考察を行った。

\section{2. 実 験 方 法}

実験装置および分析方法 ${ }^{2)}$ は前報と同じである。所定条件に調 整された亜リン酸溶液 $0.5 \mathrm{dm}^{3}$ を容積 $1 \mathrm{dm}^{3}$ の 5 ロフラスコに入れ, 窒素雾囲気下で所定温度に加熱保持後, 所定の攪拌速度で溶液を 攪拌しながら所定混合比の $\mathrm{O}_{2}-\mathrm{SO}_{2}$ 混合ガスを反応容器内に吹き 込んだ。実験中の $\mathrm{pH}$ は $\mathrm{NaOH}$ 溶液を $\mathrm{pH}$ コントローラーと電磁弁 を介して滴下させて一定に保った。

実験では所定時間ごとに抜き出した溶液は液中の亜リン酸量, リン酸量, 溶解 $\mathrm{SO}_{2}$ を求めた。また, 系外に排出された $\mathrm{SO}_{2}$ 量を 分析で求め, 送入 $\mathrm{SO}_{2}$ 量から溶解 $\mathrm{SO}_{2}$ と系外に排出された $\mathrm{SO}_{2}$ 量

* 2001 年 7 月 13 日受付 11 月 19 日受理 資源 ・素材学会平成 12 年度春季大 会において一部発表 (2000 年 3 月 28 日)

1. 普通会員 千葉工業大学助教授 金属工学科

2. 学生会員 千葉工業大学大学院生 金属工学専攻 ( 現 新神戸電機 (株))

3. 普通会員 千葉工業大学教授 金属工学科

[ 著者連絡先 ] FAX 047-478-0329 (千葉工大・金属)

キーワード: 亜リン酸, 液相酸化, 酸化刘, 亜硫酸ガス, 酸素ガス, 反応条件
の和を差し引き反応に使われた $\mathrm{SO}_{2}$ 量 (亜リン酸の酸化に消費さ れた $\mathrm{SO}_{2}$ ) を求め, 反応の物質収支を調べた。また反応に伴う $\mathrm{pH}$ 変化を補償するために $\mathrm{NaOH}$ 滴下量を測定した。

\section{3. 実 験 結 果}

基本溶液条件として $\mathrm{H}_{3} \mathrm{PO}_{3}$ 濃度は $0.1 \mathrm{~mol} / \mathrm{dm}^{3}$, 液温は $80^{\circ} \mathrm{C}$ と し, $\mathrm{pH}$ 值は無電解めっき廃液の $\mathrm{pH}$ である $4.5^{3)}$ に保つ。

攪拌速度が亜リン酸の酸化に及ぼす影響を Fig.1に示した。攪拌 速度は $750 \mathrm{~min}^{-1}, 900 \mathrm{~min}^{-1}, 1,000 \mathrm{~min}^{-1}, 1,200 \mathrm{~min}^{-1}$ と変化させ た。得られた結果を縦軸の左軸に $\mathrm{H}_{3} \mathrm{PO}_{3}$ の酸化率で, また右軸に は酸化率に対応した $\mathrm{H}_{3} \mathrm{PO}_{3}$ 酸化量を表記した。攪拌速度が大きく

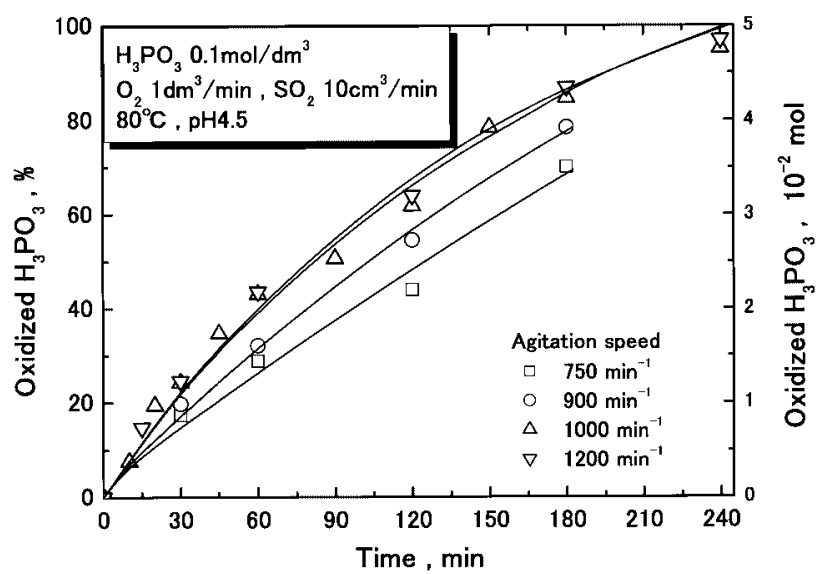

Fig.1 Effect of agitation speed on oxidation of $\mathrm{H}_{3} \mathrm{PO}_{3}$ at the $\mathrm{H}_{3} \mathrm{PO}_{3}$ concentration of $0.1 \mathrm{~mol} / \mathrm{dm}^{3}$. 


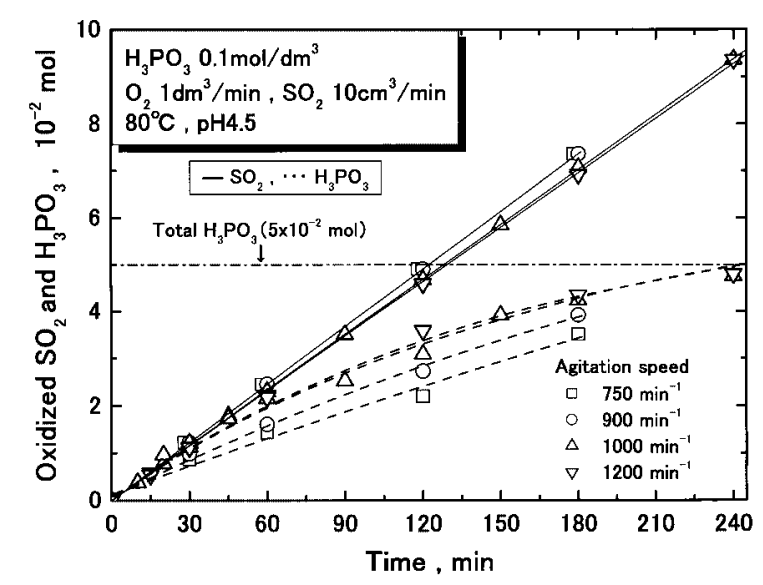

Fig.2 Relationships between the quantities oxidized $\mathrm{H}_{3} \mathrm{PO}_{3}$ and oxidized $\mathrm{SO}_{2}$, and the time at the $\mathrm{H}_{3} \mathrm{PO}_{3}$ concentration of $0.1 \mathrm{~mol} / \mathrm{dm}^{3}$.

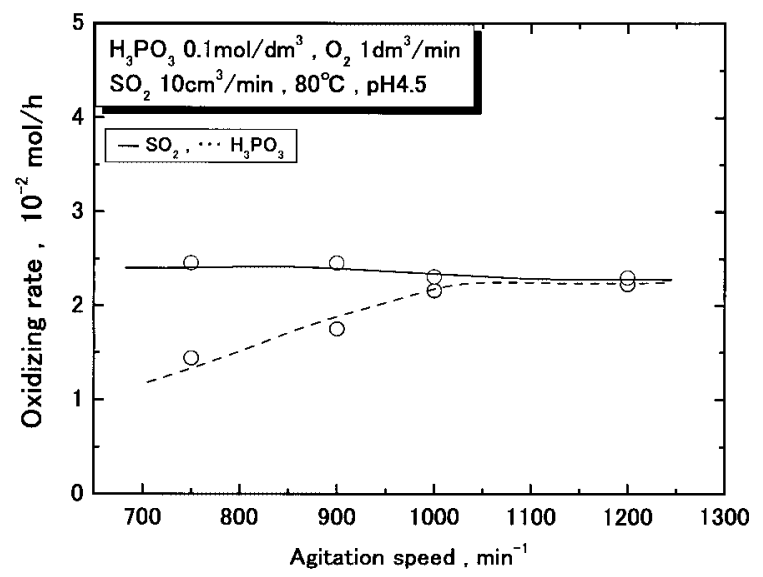

Fig.3 Effect of agitation speed on the oxidation rate of $\mathrm{H}_{3} \mathrm{PO}_{3}$ and $\mathrm{SO}_{2}$ at the $\mathrm{H}_{3} \mathrm{PO}_{3}$ concentration of $0.1 \mathrm{~mol} / \mathrm{dm}^{3}$.

なるに伴い $1,000 \mathrm{~min}^{-1}$ までは, 亜リン酸の酸化は攪拌速度の大き さとともに増加するが，それ以上の $1,200 \mathrm{~min}^{-1}$ としてもあまり変 わらない。酸化量を $180 \mathrm{~min}$ で比べると $750 \mathrm{~min}^{-1}$ では $0.035 \mathrm{~mol}($ 約 $75 \%)$ が， $900 \mathrm{~min}^{-1}$ では $0.04 \mathrm{~mol}($ 約 $80 \%), 1,000 \mathrm{~min}^{-1}$ および $1,200 \mathrm{~min}^{-1}$ では $0.045 \mathrm{~mol}($ 約 $90 \%$ ) が酸化された。

この条件下での $\mathrm{SO}_{2}$ 酸化量と $\mathrm{H}_{3} \mathrm{PO}_{3}$ 酸化量を Fig.2 に示した。 実線が $\mathrm{SO}_{2}$ 酸化量, 破線が $\mathrm{H}_{3} \mathrm{PO}_{3}$ 酸化量を示す。図中の 1 点鎖線 は全 $\mathrm{H}_{3} \mathrm{PO}_{3}$ 量 $0.05 \mathrm{~mol}$ を示寸線である。すなわちここが液中の亜 リン酸が全量リン酸に酸化されたことを示寸。 $\mathrm{SO}_{2}$ 酸化量と $\mathrm{H}_{3} \mathrm{PO}_{3}$ 酸化量がほぼ同じである時間は攪拌速度が大きくなるほど長くな る。1,000 $\mathrm{min}^{-1}$ および 1,200 $\mathrm{min}^{-1}$ においては $60 \mathrm{~min}$ までである。 それ以降は $\mathrm{SO}_{2}$ 酸化量が $\mathrm{H}_{3} \mathrm{PO}_{3}$ 酸化量より大きくなる。

この時間と $\mathrm{H}_{3} \mathrm{PO}_{3}$ 酸化曲線から初期段階 $60 \mathrm{~min}$ までの初期酸化 速度 $k(\mathrm{~mol} / \mathrm{h})$ を求め, 攪拌速度との関係を Fig.3に示した。攪拌 速度が大きくなるに伴い，溶液中の亜リン酸の酸化速度が大きく なる。しかし， $1,000 \mathrm{~min}^{-1}$ 以上 $1,200 \mathrm{~min}^{-1}$ の攪拌速度で行っ ても，ほとんど酸化速度が変わらない。以後の実験の㩭找速度は $1,000 \mathrm{~min}^{-1}$ 一定で行うことにした。

次に亜リン酸の酸化に及ぼす気相中の酸素分圧の影響について 調べた。酸素分圧は $P_{\mathrm{O}_{2}} 20 \mathrm{kPa}$ ( 空気 $\left.1 \mathrm{dm}^{3} / \mathrm{min}\right), P_{\mathrm{O}_{2}} 51 \mathrm{kPa}\left(\mathrm{O}_{2}\right.$ $500 \mathrm{~cm}^{3} / \mathrm{min}$ と $\mathrm{N}_{2} 500 \mathrm{~cm}^{3} / \mathrm{min}$ の混合 ), $P_{\mathrm{O}_{2}} 101 \mathrm{kPa}\left(\mathrm{O}_{2} 1 \mathrm{dm}^{3} / \mathrm{min}\right)$ と し, $\mathrm{SO}_{2}$ ガスはそれぞれのガスに体積比で $1 \%$ となる $10 \mathrm{~cm}^{3} / \mathrm{min}$ を 混合させ吹き込んで実験を行った。使用した各種ガスはボン心゙入 りガスを乾燥・精製せずにそのまま反応系に吹き込み使用した。

得られた結果を $\mathrm{SO}_{2}$ 酸化量と $\mathrm{H}_{3} \mathrm{PO}_{3}$ 酸化量の関係でプロットし

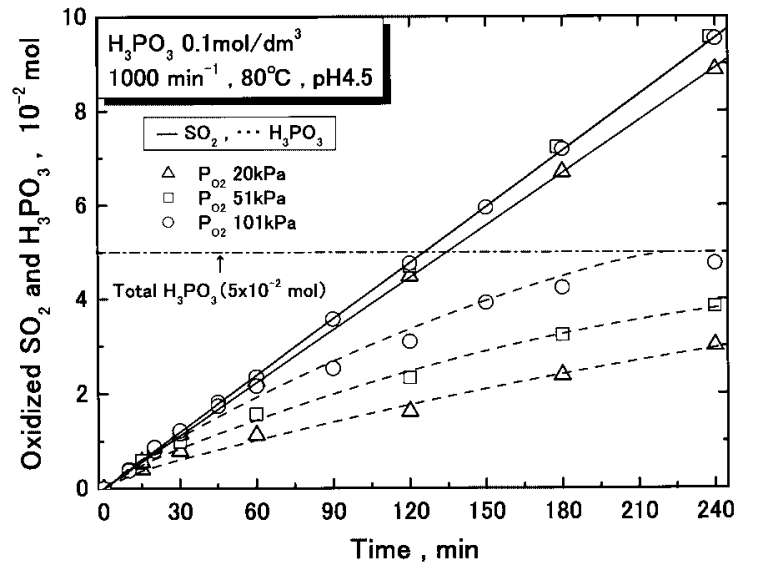

Fig.4 Effect of the partial pressure of oxygen on the quantities oxidized $\mathrm{H}_{3} \mathrm{PO}_{3}$ and oxidized $\mathrm{SO}_{2}$ at the $\mathrm{H}_{3} \mathrm{PO}_{3}$ concentration of $0.1 \mathrm{~mol} / \mathrm{dm}^{3}$.

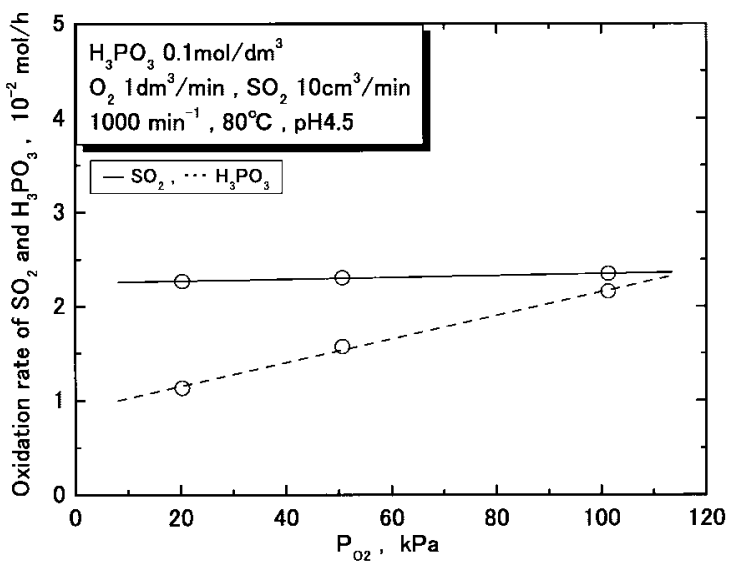

Fig.5 Effect of the partial pressure of oxygen on the oxidation rate of $\mathrm{H}_{3} \mathrm{PO}_{3}$ and $\mathrm{SO}_{2}$ at the $\mathrm{H}_{3} \mathrm{PO}_{3}$ concentration of $0.1 \mathrm{~mol} / \mathrm{dm}^{3}$.

Fig.4に示した。気相中の酸素分圧が大きくなるに伴い, 亜リン酸 の酸化は進行する。240min で比較した場合，20kPa では約 $60 \%$, $51 \mathrm{kPa}$ では約 $80 \% ， 101 \mathrm{kPa}$ ではほとんどがリン酸に酸化された。

このときの $\mathrm{H}_{3} \mathrm{PO}_{3}$ 酸化量と $\mathrm{SO}_{2}$ 酸化量を比較した場合, 酸素分 圧が大きくなるほど両者の酸化量がほぼ同じである時間は長くな るが, $\mathrm{H}_{3} \mathrm{PO}_{3}$ 酸化量は 液中の $\mathrm{H}_{3} \mathrm{PO}_{3}$ 量が少なくなるので, 低下 する。このため $\mathrm{H}_{3} \mathrm{PO}_{3}$ 酸化量に比べて $\mathrm{SO}_{2}$ 酸化量が大きくなる。 両者が同じである時間は $P_{\mathrm{O}_{2}} 20 \mathrm{kPa}$ では $60 \mathrm{~min}, P_{\mathrm{O}_{2}} 51 \mathrm{kPa}$ では 30min であった。

Fig.4の初期段階 60min までの直線の勾配から亜リン酸と $\mathrm{SO}_{2}$ の 初期酸化速度 $k(\mathrm{~mol} / \mathrm{h})$ を求め, 酸素分圧との関係で Fig.5 に示し た。亜リン酸のリン酸への酸化は酸素分圧にほぼ比例して進行し ており, $\mathrm{H}_{3} \mathrm{PO}_{3}$ の酸化反応は酸素分圧に大きく依存することがわ かった。一方 $\mathrm{SO}_{2}$ の酸化速度は酸素分圧を大きくしてもほとんど 変わらず，この実験条件範囲内では酸素分圧に影響されない。

次に, 亜リン酸の酸化に及ぼす溶液 $\mathrm{pH}$ の影響について調べた。 溶液の $\mathrm{pH}$ を 1.0，2.0，3.0，4.5 と変化させた。この条件下での $\mathrm{SO}_{2}$ 酸化量と $\mathrm{H}_{3} \mathrm{PO}_{3}$ 酸化量をプロットした結果を Fig.6に示した。 $\mathrm{pH}$ 值が大きくなるに伴い亜リン酸の酸化は少し大きくなる傾向 にある。覀リン酸の酸化量と $\mathrm{SO}_{2}$ 酸化量が同じである時間は $\mathrm{pH}=4.5$ において $60 \mathrm{~min}$ まで, $\mathrm{pH}=1.0,2.0,3.0$ では $30 \mathrm{~min}$ までで あり, それ以降 $\mathrm{H}_{3} \mathrm{PO}_{3}$ 酸化量は $\mathrm{SO}_{2}$ 酸化量に比べ小さくなる。

Fig.6からのそれぞれ初期酸化速度 $k(\mathrm{~mol} / \mathrm{h})$ を求め, $\mathrm{pH}$ との関 係でFig.7 に示した。溶液の $\mathrm{pH}$ の上昇に伴い, 亜リン酸の酸化速 度は大きくなる。これは $\mathrm{H}_{3} \mathrm{PO}_{3} / \mathrm{H}_{2} \mathrm{PO}_{3}^{-}$の $\mathrm{pk}$ がほぼ 2 であり, 


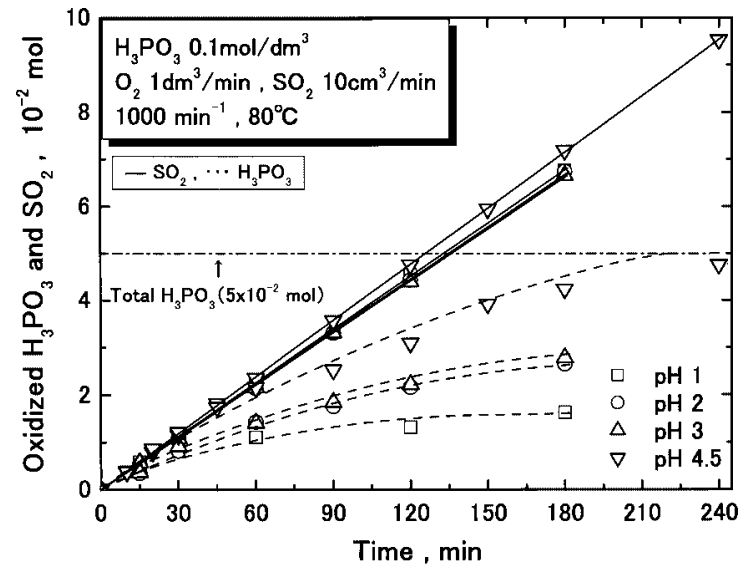

Fig.6 Effect of the $\mathrm{pH}$ value on the quantities oxidized $\mathrm{H}_{3} \mathrm{PO}_{3}$ and oxidized $\mathrm{SO}_{2}$ at the $\mathrm{H}_{3} \mathrm{PO}_{3}$ concentration of $0.1 \mathrm{~mol} / \mathrm{dm}^{3}$.

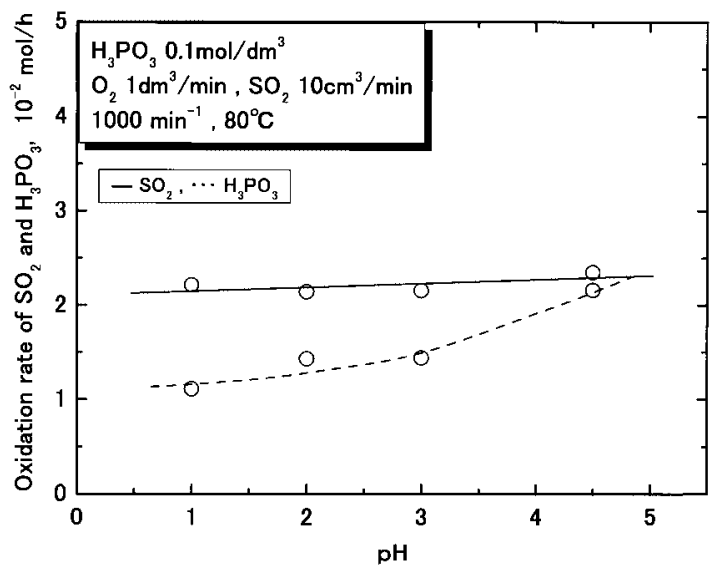

Fig.7 Effect of the $\mathrm{pH}$ value on the oxidation rate of $\mathrm{H}_{3} \mathrm{PO}_{3}$ and $\mathrm{SO}_{2}$ at the $\mathrm{H}_{3} \mathrm{PO}_{3}$ concentration of $0.1 \mathrm{~mol} / \mathrm{dm}^{3}$.

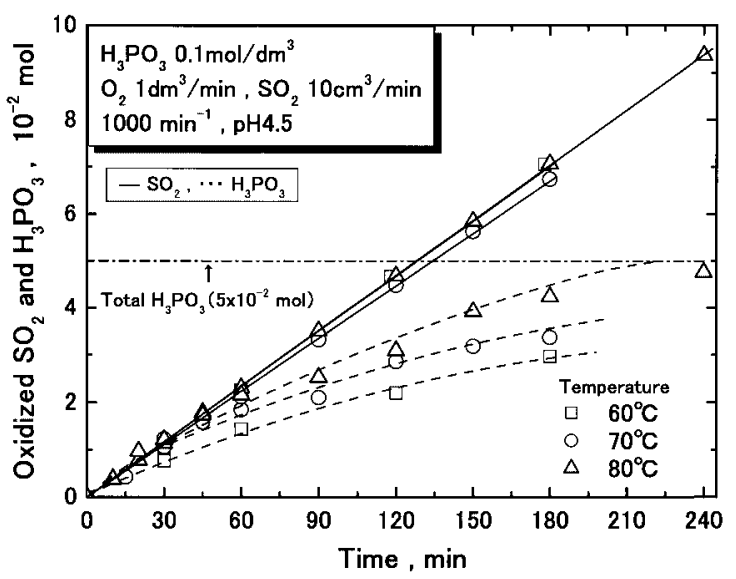

Fig.8 Effect of the solution temperature on the quantities oxidized $\mathrm{H}_{3} \mathrm{PO}_{3}$ and oxidized $\mathrm{SO}_{2}$ at the $\mathrm{H}_{3} \mathrm{PO}_{3}$ concentration of $0.1 \mathrm{~mol} / \mathrm{dm}^{3}$.

$\mathrm{pH}$ とともにプロトン配位が変化することと関係するものと思わ れる。 $\mathrm{pH}$ の大きい方が亜リン酸の酸化には有利といえる。一方, $\mathrm{SO}_{2}$ の酸化速度にはこの範囲内では $\mathrm{pH}$ の影響は見られない。

次に, 液温の亜リン酸の酸化に及ぼす影響について調べた。液 温は $60^{\circ} \mathrm{C}, 70^{\circ} \mathrm{C}, 80^{\circ} \mathrm{C}$ とした。この条件下での $\mathrm{SO}_{2}$ 酸化量と $\mathrm{H}_{3} \mathrm{PO}_{3}$ 酸化量を比較したものが Fig.8である。

いずれの温度においても時間の経過とともに亜リン酸の酸化は 進行し，液温が上がるにつれて亜リン酸の酸化速度は大きくなる ことがわかる。どの条件においてもほぼ $60 \mathrm{~min}$ までは直線的に

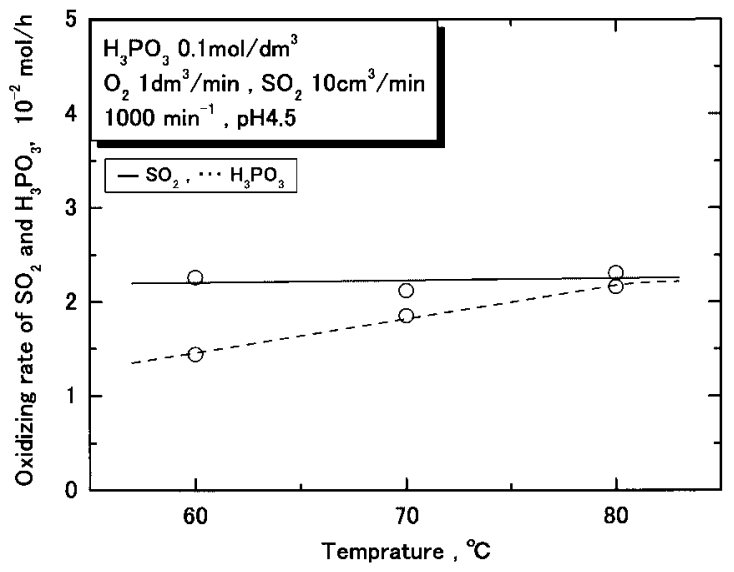

Fig.9 Effect of the solution temperature on the oxidation rate of $\mathrm{H}_{3} \mathrm{PO}_{3}$ and $\mathrm{SO}_{2}$ at the $\mathrm{H}_{3} \mathrm{PO}_{3}$ concentration of $0.1 \mathrm{~mol} / \mathrm{dm}^{3}$.

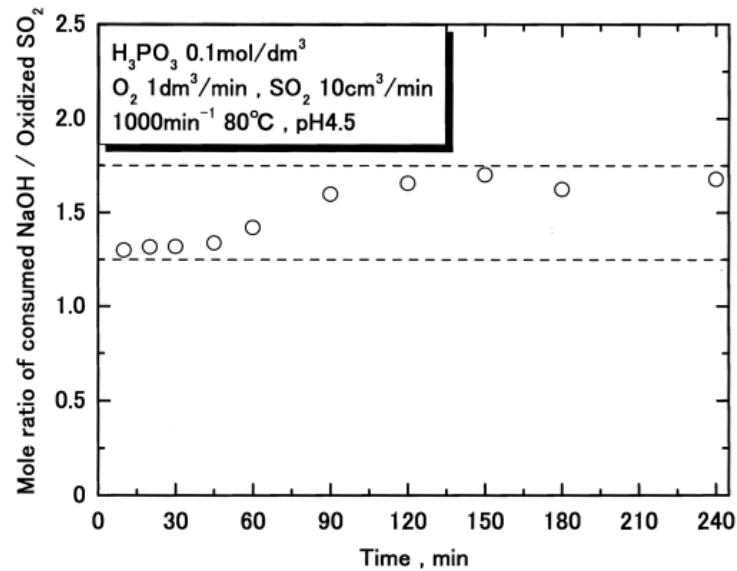

Fig.10 Relationship between the mole ratio of quantities oxidized $\mathrm{SO}_{2}$ and the quantities consumed $\mathrm{NaOH}$ for the $\mathrm{pH}$ adjustment and time.

$\mathrm{H}_{3} \mathrm{PO}_{3}$ の酸化は進行しているが，それ以降になると時間経過とと もに低下寸る。 $\mathrm{H}_{3} \mathrm{PO}_{3}$ の酸化量は反応時間 $180 \mathrm{~min}$ で比較すると $60{ }^{\circ} \mathrm{C}$ で $0.027 \mathrm{~mol}($ 約 $55 \%), 70{ }^{\circ} \mathrm{C}$ で $0.032 \mathrm{~mol}($ 約 $65 \%), 80{ }^{\circ} \mathrm{C}$ で $0.045 \mathrm{~mol}($ 約 $90 \%$ ) である。

また, $\mathrm{SO}_{2}$ 酸化量と $\mathrm{H}_{3} \mathrm{PO}_{3}$ 酸化量が同じである時間は $70^{\circ} \mathrm{C}$, $80{ }^{\circ} \mathrm{C}$ においては $60 \mathrm{~min}$ まで, $60^{\circ} \mathrm{C}$ では $30 \mathrm{~min}$ までであり, それ 以降は $\mathrm{SO}_{2}$ 酸化量が $\mathrm{H}_{3} \mathrm{PO}_{3}$ 酸化量より多くなる。

Fig.8 から初期段階 60min までの初期酸化速度 $k$ を求め, 液温と の関係で Fig.9 に示した。液温を上げると亜リン酸の酸化速度は 大きくなり，これらの関係は比例関係となる。一方, $\mathrm{SO}_{2}$ の酸化 速度には温度はほとんど影響しない。この Fig.9 における初期反応 速度の温度変化の勾配から $\mathrm{H}_{3} \mathrm{PO}_{3}$ 酸化の見掛けの活性化エネル ギーを求めると約 $10 \mathrm{~kJ} / \mathrm{mol}$ であった。この温度依存は一般的に水 溶液中の拡散に支配される場合に相当し，大きな温度依存性では ない。

次に, 溶液 $\mathrm{pH}$ の調整液に使用した $\mathrm{NaOH}$ の役割について以下 の検討を行った。

まず，前報の結果も含めて反応条件との結果で整理すると，酸 素単独, 窒素に $\mathrm{SO}_{2}$ を搬送させたガスおよび窒素単独吹き込みで は, $\mathrm{H}_{3} \mathrm{PO}_{3}$ の酸化はほとんど進行せず, また $\mathrm{pH}$ 調整溶液の $\mathrm{NaOH}$ は実験開始時から全く消費されなかった。それに対して, 酸素に $\mathrm{SO}_{2}$ を混合したガスを吹き込んだ場合は, 時間経過とともに $\mathrm{H}_{3} \mathrm{PO}_{3}$ の酸化は進行し, それに対応して $\mathrm{NaOH}$ も滴下されていくのでそ の消費量が大きくなる。

ここでは基本条件 $\mathrm{O}_{2}-\mathrm{SO}_{2} 1 \%$ 混合ガスについて Fig. 10 に $\mathrm{NaOH}$ 
消費量と $\mathrm{SO}_{2}$ 酸化量の関係 (モル比) を示した。実験開始から終 了まで約 $1.3 \sim 1.7$ を示し，1 以下または 2 以上にはならないこと がわかる。この関係は $\mathrm{O}_{2}-\mathrm{SO}_{2}$ 混合ガスを吹き込んだすべての実 験において同様であった。

ガス中の $\mathrm{SO}_{2}$ 濃度が大きくなるとともに $\mathrm{SO}_{2}$ 酸化量はほぼ比例 して大きくなり，また $\mathrm{NaOH}$ 消費量も同様であった。 $\mathrm{O}_{2}$ に $\mathrm{SO}_{2}$ を 混合したすべての条件下においても未反応として系外に排出した $\mathrm{SO}_{2}$ 量はなく, また水溶液中に残留している $\mathrm{SO}_{2}$ 量は極微量であっ た。したがって送入した $\mathrm{SO}_{2}$ のほとんどが酸化される結果となっ た。また, 寸べての実験条件において, 前報と同じく $\mathrm{H}_{3} \mathrm{PO}_{3}$ 酸化 量が $\mathrm{SO}_{2}$ 酸化量を超えることはなかった。

これらの結果を踏まえて, 以下の考察を行った。

\section{4. 考察}

前報では $\mathrm{SO}_{2}, \mathrm{H}_{3} \mathrm{PO}_{3}$ の酸化反応を次の 4 つの電気化学的単極 反応の組合せで説明した。

酸素の還元 :

$\mathrm{O}_{2}+\mathrm{H}_{2} \mathrm{O}+2 \mathrm{H}^{+}+2 \mathrm{e}^{-}=\mathrm{H}_{2} \mathrm{O}_{2}$

$\mathrm{H}_{2} \mathrm{O}_{2}+2 \mathrm{H}^{+}+2 \mathrm{e}^{-}=2 \mathrm{H}_{2} \mathrm{O}$

亜リン酸の酸化 :

$\mathrm{PO}_{3}{ }^{2-}+\mathrm{H}_{2} \mathrm{O}-2 \mathrm{e}^{-}=\mathrm{PO}_{4}{ }^{2-}+2 \mathrm{H}^{+}$

二酸化硫黄の酸化 :

$\mathrm{SO}_{2}+2 \mathrm{H}_{2} \mathrm{O}-2 \mathrm{e}^{-}=\mathrm{SO}_{4}{ }^{2-}+4 \mathrm{H}^{+}$

前報で述べた仮説は, (1) 均一相内で式 (1) の反応は式 (4) との組 合せで進行するが，式 (3) との組合せでは進行しない, (2) 式 (2) と 式 (3) の組合せ, また式 (2) と式 (4) の組合せはいずれも進行する, の 2 項目からなる。

この仮説の要点は, 水溶液に溶解した分子状酸素の酸化力が有 効に作用するためには $\mathrm{O}_{2}$ を分解する式(1) で表される第 1 段の反 応が必要であると考えている点にある。第 1 段の反応では酸素は $\mathrm{H}_{2} \mathrm{O}$ まで還元されずに, まだ酸化力を残している中間産物を生じ, その中間産物が亜リン酸の酸化を進行させる。

このような中間産物としては, $\mathrm{H}_{2} \mathrm{O}_{2}$ が現在知られている化合物 の中でこの条件に合うという理由で式 (1) に $\mathrm{H}_{2} \mathrm{O}_{2}$ を取り上げた。 この実験では, $\mathrm{H}_{2} \mathrm{O}_{2}$ の存在を確認できてはいないが, 酸化力を残 している中間産物を代表する化学種という意味で $\mathrm{H}_{2} \mathrm{O}_{2}$ と書くこ とが許されるものと考えている。

実験的に明らかにした反応の化学量論は, このような単位反応 を組合せて次のような形で述べることができる。

まず $\mathrm{SO}_{2}$ の酸化によって分子状酸素が中間産物である $\mathrm{H}_{2} \mathrm{O}_{2}$ を 生じる。

$\mathrm{SO}_{2}+2 \mathrm{H}_{2} \mathrm{O}+\mathrm{O}_{2}=\mathrm{H}_{2} \mathrm{SO}_{4}+\mathrm{H}_{2} \mathrm{O}_{2}$

この $\mathrm{H}_{2} \mathrm{O}_{2}$ は $\mathrm{H}_{3} \mathrm{PO}_{3}$ および $\mathrm{SO}_{2}$ を酸化する

$\mathrm{H}_{3} \mathrm{PO}_{3}+\mathrm{H}_{2} \mathrm{O}_{2}=\mathrm{H}_{3} \mathrm{PO}_{4}+\mathrm{H}_{2} \mathrm{O}$

$\mathrm{SO}_{2}+\mathrm{H}_{2} \mathrm{O}_{2}=\mathrm{H}_{2} \mathrm{SO}_{4}$

これらは先に Tiwari $5^{4)}$ が提案した説を支持するものである。

著者ら ${ }^{5)}$ は先に $\mathrm{SO}_{2}$ が分子状酸素を活性化するという形でこれ らの現象を説明したが, 今回の化学量論的な結果として, より具
体的な形での理解が可能となった。

酸化過程で反応溶液の $\mathrm{pH}$ を一定に保つために消費した $\mathrm{NaOH}$ 量の測定の結果をFig.10に示したが,これは次のような意図で行っ た。反応系に吹き込まれた $\mathrm{SO}_{2}$ が $\mathrm{SO}_{4}{ }^{2-}$ に酸化される過程で, 結 果として, 式 (5), (7) から $\mathrm{SO}_{2} 1 \mathrm{~mol}$ に対して $2 \mathrm{~mol}$ の $\mathrm{H}^{+}$イオン を生じ, $\mathrm{pH}$ を一定に保つには $2 \mathrm{~mol}$ の $\mathrm{NaOH}$ を必要とすることに なる。

次に式 (5) で生成する $\mathrm{H}_{2} \mathrm{O}_{2}$ が式 (6) で消費される場合のプロト ンの収支を考える。Proubax のリン水系電位 $-\mathrm{pH}$ 図 ${ }^{6)}$ から判断す ると $\mathrm{pH} 4.5$ の領域において亜リン酸は $\mathrm{H}_{2} \mathrm{PO}_{3}{ }^{-}$, リン酸は $\mathrm{H}_{2} \mathrm{PO}_{4}{ }^{-}$ という化学種が安定であり, このことを考慮に入れると式 (6) は 次のように書くことができる。

$\mathrm{H}_{2} \mathrm{PO}_{3}{ }^{-}+\mathrm{H}_{2} \mathrm{O}_{2}=\mathrm{H}_{2} \mathrm{PO}_{4}{ }^{-}+\mathrm{H}_{2} \mathrm{O}$

すなわち, この反応ではプロトン生成はないので, $\mathrm{NaOH}$ の消 費量には関係がない。このことは Fig.10 の NaOH 消費量が 2 であ ると説明つけやすいが, 実験結果では $1.3 \sim 1.7$ であり, 説明がつ かない。このことの説明としては, $\mathrm{SO}_{2}$ 酸化生成物の一部が 6 価 の $\mathrm{SO}_{4}{ }^{2-}$ まで到達せずに, $\mathrm{S}_{2} \mathrm{O}_{6}{ }^{2-}$ ような低原子価化合物のレベル に止まった可能性が考えられる。今回の研究ではこの点の解明は できていない。

\section{5. 結訔}

前報に引き続き, 亜リン酸を含む酸性溶液中に $\mathrm{O}_{2}$ と $\mathrm{SO}_{2}$ の混 合ガスを吹き込み亜リン酸のリン酸への酸化挙動を調べた。反応 条件として攪汼速度, 酸素分圧, $\mathrm{pH}$, 溶液温度などを取り上げ, それらが亜リン酸および亜硫酸の初期酸化速度に与える影響を調 べ, 酸化反応機構について検討した。得られた結果をまとめると 以下のようになる。

（1）攪拌速度が大きくなるにつれ, 亜リン酸の初期酸化速度は 大きくなるが $1,000 \mathrm{~min}^{-1}$ 以上ではほとんど変わらない。

(2) 酸素分圧を変化させて行った場合, 覀リン酸の初期酸化速 度は酸素分圧に比例する。

（3）溶液の $\mathrm{pH}$ を上げると亜リン酸の初期酸化速度は大きくな る。

（4）液温の上昇に比例して亜リン酸の初期酸化速度は大きく なるが，酸化速度の温度依存性は大きくはない。

(5) すべての反応条件において $\mathrm{H}_{3} \mathrm{PO}_{3}$ 酸化量は $\mathrm{SO}_{2}$ 酸化量を 超えることはなかった。また, 本実験範囲内ではいずれの反応の パラメータも $\mathrm{SO}_{2}$ の酸化速度には影響を示さなかった。

おわりに, 本研究の一部は科学研究費補助金 (基盤研究 (B2)) 課 題番号 12450305 で行われたことを記して謝意を表する。

\section{引 用 文 献}

）山下智司・近藤隆文・増子 暃: 資源と素材, Vol.118, p.54-58, (2002)

2) 上野景平 : キレート滴定法, p. 203-207,(1989), 南江堂 (東京)

3) 神戸徳蔵：無電解めつきの応用, p.155, (1984), 槇書店 (東京)

4) Tiwari, B.L., Kolbe, J. and Hayden, Jr.W.: Oxidation of ferrous sulfate in acidic solution by a mixture of sulfur dioxide and oxygen, Metallurgical Transaction 10B, p.607-612 (1979)

5) Yamashita, S., Hata, K. and Goto, S.: Zinc \& Lead '95(Sendai), p.492-501, (1995)

6) Pourbaix, M. : Atlas Electrochemical Equilibria in Aqueous Solutions, Nace Cebelcor, p.504-511, (1966) 